\title{
Effect of high-level fish meal replacement by plant proteins in gilthead sea bream (Sparus aurata) on growth and body/fillet quality traits
}

\author{
M. De Francesco ${ }^{1}$, G. Parisi ${ }^{1}$, J. Pérez-Sanchez ${ }^{2}$ P. Gomez-Réqueni ${ }^{2}$, F. Médale ${ }^{3}$, S.J. Kaushik ${ }^{3}$, M. \\ Mecatti ${ }^{1}$ \& B.M. Poli ${ }^{1, *}$
}

\footnotetext{
${ }^{1}$ Dipartimento di Scienze Zootecniche, Università degli Studi di Firenze, Florence, Italy

2 Instituto de Acuicultura de Torre de la Sal (CSIC), Castellòn, Spain

${ }^{3}$ Fish Nutrition Laboratory, UMR NuAGe, INRA-IFREMER - Univ. Bordeaux I, Station d'Hydrobiologie, Saint Pée-sur-Nivelle, France
}

*: Corresponding author : Poli B. M., email address : biancamaria.poli@unifi.it

\begin{abstract}
:
Juvenile gilthead sea bream (initial body weight ca. $100 \mathrm{~g}$ ) were reared in an indoor flow through marine water system for 1 year. Fish were fed two isoenergetic $\left[19.2 \mathrm{~kJ} \mathrm{~g}^{-1}\right.$ dry matter (DM)] and isoproteic (426 g kg${ }^{-1} \mathrm{DM}$ ) diets either based on fish meal (diet FM) or on a mixture of plant protein sources (diet PP), replacing $75 \%$ of fish meal protein. The growth trial was conducted in duplicate, two tanks for each dietary treatment. Growth performance and feed utilization were registered. Fillet quality parameters were evaluated and sensory analyses on cooked fillet were performed. Both groups had similar weight gain and specific growth rates. Feed intake was higher in sea bream fed diet FM (0.48 versus 0.44 ), while feed efficiency and protein efficiency ratio were significantly higher in sea bream fed PP ( 0.83 versus 0.77 and 2.0 versus 1.76 , respectively). Sea bream fed diet FM had a lower hepatosomatic index ( 0.80 versus $0.87 \%)$, and a higher fillet yield ( 45.9 versus $44.9 \%)$. The fillet from sea bream fed diet FM had higher moisture (696 versus $682 \mathrm{~g} \mathrm{~kg}^{-1}$ ), lower lipid levels (91 versus $100 \mathrm{~g} \mathrm{~kg}^{-1}$ ) with higher levels of $\mathrm{n}-3$ polyunsaturated fatty acids (PUFA) and monounsaturated fatty acids (MUFA), while the PP fed sea bream presented a higher level of PUFA $n-6$. There were minor differences in muscle free amino acid levels between the two diet groups. As regards sensory evaluation of cooked fillet, the judges were unable to discriminate the two dietary groups of fish. Summarizing, the results demonstrate the possibility to use diets containing high levels $\left(750 \mathrm{~g} \mathrm{~kg}^{-1}\right)$ of plant ingredients in gilthead sea bream without affecting growth performance and with minor effects on quality traits of commercial size sea bream.
\end{abstract}

Keywords: chemical composition $\cdot$ gilthead sea bream $\cdot$ plant protein $\cdot$ quality traits - sensory evaluation $\cdot$ Sparus aurata 


\section{Introduction}

Production of gilthead sea bream in the Mediterranean area has increased remarkably over the past decade reaching more than 80000 tons and the forecasts indicate further increase in marine finfish production (FAO, 2003). The question of sustainable development of aquaculture in the general context of increasing demand combined with the relative stability in supply of fish meal and fish oil (New and Wijkstroem, 2002) is a very contemporary issue. Development of feeds with significantly reduced levels of fish meal and fish oil is recognised by all as a major step towards reducing the pressure on scarce marine resources at a global level (FAO, 2001). At the farm level, the substitution of fish meal could have a positive effect on production costs (Hardy, 1996) as well as on aquaculture waste management by lowering the content in phosphorus (Storebakken et al., 2000; Kaushik et al., 2004) and or nitrogen responsible for eutrophication (Tacon and Forster, 2003). Possible amino acid imbalance and the presence of antinutritional factors often limit the use of terrestrial plant ingredients in fish feed (Kaushik, 1990; Tacon, 1997; Francis et al., 2001). In rainbow trout, total replacement of fish meal by plant proteins did not affect fish growth (Kaushik et al., 1995; Watanabe et al., 1998), although long term feeding with plant protein based diets results in reduced weight gain in large size rainbow trout (de Francesco et al., 2004). Improvements in feed preparing technologies and the possibility to add synthetic amino acids have enabled promising results in different marine species fed with diet containing up to $30 \%$ of plant protein (Robaina et al., 1995; Burel et al., 2000; Gouveia and Davies, 2000; Kissil et al., 2000; Pereira and Oliva-Teles, 2002). Inclusion of high percentage level (from $50 \%$ to $100 \%$ ) of plant protein in feedstuff for marine species, generally results in growth reduction (Burel et al., 2000; Kissil et al., 2000). However, recent studies suggest that almost total replacement of fish meal by vegetable ingredients in diet for European sea bass does not affect fish growth or feed utilisation 
(Kaushik et al., 2004). In a recent study that represent an earlier phase of our work, Gómez-Requeni et al. (2004) found that replacement of 50 or $75 \%$ of fish meal in diet for juveniles sea bream, led to slightly decreased growth performance in comparison to fish fed a fish meal based diet, but that a total substitution of fish meal reduced growth performances by about $30 \%$. In the present study we tested the same diets used by Gómez-Requeni et al. (2004), in the same rearing conditions, for evaluating their effects in a long duration trial, from on-growing up to market size sea bream, focalising our attention on quality aspects.

The effect of plant protein ingredients in feeds for farmed fish on chemical composition of muscle show contrasting results. Some studies have reported that inclusion of increasing levels (from 10\% to 30\%) of plant ingredients in feed for European sea bass (Gouveia and Davies, 2000) or gilthead sea bream (Pereira and Oliva-Teles, 2002) does not affect the whole body lipid content. On the other hand, Robaina et al. (1998) observed a decrease in muscle total lipid content in sea bream fed diet containing $30 \%$ of soy by products and Kissil et al. (2000) reported a decrease in whole body lipid content in sea bream fed a $100 \%$ of fish meal substitution diets based either on soybean or rapeseed protein concentrates. In contrast with these results an increase of fat in fish fed diets containing increasing level of plant ingredients was observed in trout (Burel et al., 2000) and in sea bass (Kaushik et al., 2004). In marine fish, Aoki et al. (1996) did not find any difference in flesh quality between adult red sea bream fed with or without fish meal as dietary protein source. Kaushik et al. (1995) and de Francesco et al. (2004) showed that in rainbow trout fed diets containing plant ingredients the organoleptic characteristics were slightly affected by dietary protein source. Given the lack of information on the effects of dietary plant protein sources on flesh quality of marketable size gilthead sea bream, the aim of the present study was to evaluate the effect of a high percentage of fish meal replacement by a mixture of plant protein sources on growth, 
morphological traits and quality of commercial sized gilthead sea bream reared over a full annual cycle.

\section{Materials and methods}

$\underline{\text { Diets }}$

Two isoenergetic and isoproteic (gross energy $19.2 \mathrm{k} \mathrm{Jg}^{-1} \mathrm{DM}$; crude protein $426 \mathrm{~g} \mathrm{~kg}^{-1}$ DM) diets, formulated to contain either fish meal as the exclusive protein source (diet FM) or $75 \%$ of protein from fish meal supplied by a mixture of plant protein sources such as corn gluten meal, wheat gluten, extruded peas, rapeseed meal and extruded whole wheat (diet PP), were used in this study (Table 1). Crystalline amino acids were added to the plant protein-based diet to meet the IAA requirement profile according to the NRC (1993). All dry ingredients were mixed and pelleted dry (4 mm diameter) using a Simon-Heese (Boxtel, Netherlands) pelleting machine. The PP diet was free of genistein and daidzein and had a negligible estrogenic potency. The proximate composition of the diets was determined according to the A.O.A.C. (1990) (Table 1). The fatty acid composition of the diets is reported in Table 2, while the amino acids profile of the tested diets has been previously described by Gómez-Requeni et al. (2004). The diets were stored at $4^{\circ} \mathrm{C}$ during the trial.

\section{Growth trial}

Sea bream ( $S$. aurata) were reared in the experimental rearing facilities of CSIC (Institute of Aquaculture, Torre de la Sal, Spain) in an indoor flow trough filtered marine water system, in circular glass fiber tanks (3000 1). Daylength followed natural changes, salinity was $37.5 \mathrm{~g} \mathrm{~L}^{-1}$, water flow was $100 \mathrm{l} / \mathrm{min}$ and oxygen content of outlet water was daily monitored and always higher than $85 \%$ of saturation. As we used natural marine water, the temperature reflected seasonal changes in this Mediterranean 
area (latitude: $40^{\circ} 5^{\prime} \mathrm{N}, 0^{\circ} 10^{\prime} \mathrm{E}$ ), where gilthead sea bream is normally grown (Fig.1), ranging from 10 to $25^{\circ} \mathrm{C}$. Sea bream, obtained from a commercial hatchery (CUPIMAR, Cádiz, Spain), were adapted to the experimental condition over twenty days and were fed commercial diets until the start of the study. Duplicate groups of 60 fish (average initial body weight $99.4 \mathrm{~g}$ ) were hand-fed the respective diets to visual satiety in one (cold season) or two (warm season) meals over one year. The fish were group-weighed and counted each month, under moderate anaesthesia (3-aminobenzoic acid ethyl ester, MS 222; $100 \mu \mathrm{g} / \mathrm{ml}$ ) after overnight fasting, to gain information on growth and feed intake. At the end of the growth trial, sea bream were kept unfed for two days, then were cold stunned, sacrificed by a blow on the head and stored at $3-4{ }^{\circ} \mathrm{C}$ on ice.

\section{$\underline{\text { Whole body measurements and chemical composition analyses }}$}

Fish (n=100 FM and n=100 PP) were individually weighed, and the following measurements were made using an orthometric meter: total and standard length $(\mathrm{cm})$, head length $(\mathrm{cm})$, and maximum height $(\mathrm{cm})$ (Fig.2). From linear and weight measures, morphometric indices, such as the condition factor $=\left(100 \mathrm{x}\right.$ body weight/total length $\left.{ }^{3}\right)$, agility index (distance between caudal plane and maximum height plane/maximum height), cranial index (head length/total length) and relative profile (maximum height/total length) (Geri et al., 1994), were computed. Whole body composition was determined in a pooled sample of 10 fish at the beginning and in pools of 5 fish per tank at the end of growth trial. Specimens for body analysis were ground, and small aliquots were dried $\left(105^{\circ} \mathrm{C}\right)$ to estimate water content. The remaining samples were freeze-dried and chemical analysis for protein, fat and ash was performed according to the A.O.A.C (1995). Based on data from chemical composition at the beginning and at the end of the trial, retention efficiencies and daily nitrogen and fat gains were calculated. 
One hundred and thirty two fish were completely dissected (n=66 FM and n=66 PP), and the main body components (fins, gills, head, liver, digestive tract, mesenteric fat, viscera) were weighed and their relative incidence to whole body mass were computed. The dressed weight $(\%)$ and fillet yield (fillets with skin, $\%$ of body weight) were also calculated, this last computed as twice the right fillet weight. Due to the complexity of the experimental design the protocol previewed to use different part of the same fish for various analyses, thus it was impossible to conform the number of subjects used for different determinations such as morphometric data, body components, commercial traits, fillet composition and liver composition. This is the reason why in the tables 4-8, the number of samples is very variable.

$\underline{\text { Proximate analysis, fatty acid composition and free amino acids }}$

Fillets and livers were vacuum packed and stored on dry ice prior to chemical composition analysis: moisture, crude protein, ash and phosphorus according to A.O.A.C. (1995) and total lipids according to Folch et al. (1957). Fatty acid composition of fillets (30 for each diet) and livers ( 8 samples for each diet, obtained grouping the liver of 3 different fish from the same tank) was analysed by quantitative gas chromatography (utilising $\mathrm{C} 23: 0$ as internal standard) on the extracted lipids (Morrison and Smith, 1964). Atherogenicity and thrombogenicity indexes were also calculated (Ulbricht and Southgate, 1991). Total cholesterol content was determined by chromatography (utilising colestane as internal standard), in isotermic conditions (290 ${ }^{\circ} \mathrm{C}$ ) with a capillary column (Supelco SPBT -5: 30m, id 0,32 mm film 0,25 mm).

From 6 fish per dietary treatment, immediately after death and after 11 days of refrigerated storage, a sample of the anterior portion of the dorsal muscle was withdrawn, frozen in liquid nitrogen and stored at $-80{ }^{\circ} \mathrm{C}$ to analyse the free amino acids 
content after a trichloroacetic acid (1g muscle/ $9 \mathrm{ml}$ TCA 10\%) extraction by HPLC with a post column ninydrine derivatization (Moore and Stein, 1951).

The free amino acids content was analysed at the beginning of the shelf-life and at the $11^{\text {th }}$ days after death (Scheme 1), when fish of both group were judged as unfit by a trained panel test (unpublished data), to evaluate eventual modifications on this parameters in not edible fish.

\section{$\underline{\text { Degradation products }}$}

The malonaldehyde-TBA complex with solid-phase extraction (Raharjo et al., 1993) for oxidised lipids was determined on whole fillet at 2, 6 , and 9 days of refrigerated storage (Scheme 1).

\section{$\underline{\text { Instrumental colour measurement }}$}

Colour measures were made using a CR-200 Chroma Meter (Minolta, U.K.), each day from the death until the end of the shelf life (when fish were judged as unfit for human consumption) (Scheme 1). Colorimetric measurements on whole sea bream ( $\mathrm{n}=82$ for each diet) stored on ice at $1{ }^{\circ} \mathrm{C}$ were made in three different skin sites (opercular, abdominal and rostral) in order to analyse the eventual colour spots. Therefore on intact right fillets ( $\mathrm{n}=64$ for each diet), withdrawn at different sampling time from whole fish stored at $3-4{ }^{\circ} \mathrm{C}$, the colour measurements were made at the cephalic epaxial, ventral and caudal sites. Triplicate measurements were taken at each site, to give a mean value for each area. Data were expressed using the $\mathrm{L}^{*} \mathrm{a}^{*} \mathrm{~b}^{*}$ system, representing lightness, redness and yellowness as indicated by the CIE (1976); in addition, the values of the chroma $\left[\sqrt{ }\left(a^{*^{2}}+\mathrm{b}^{*^{2}}\right)\right]$, which defines the saturation of colour, and the angle of hue $\left[\tan ^{-1}\left(\mathrm{~b}^{*} / \mathrm{a}^{*}\right)\right]$ were calculated. 


\section{$\underline{\text { Sensory evaluation on cooked fillet }}$}

A sensory evaluation was made on fillets withdrawn from whole fish stored with ice at $1{ }^{\circ} \mathrm{C}$, after 3 days of refrigerated storage, when sea bream were still fresh, and after 7 days, when sea bream were still edible (Scheme 1). The epaxial portion of each fillet with skin was divided into 4 portions ( 8 portions from each fish), wrapped in a special microwave oven paper and cooked in a microwave oven (Moulinex Optiquick Compact), at 500 watt for 50 seconds. A trained panel consisting of 9 judges evaluated in duplicate by a triangular test (ISO, 1983) the fillet portions in air-conditioned individual boxes, designed for sensory analysis (ISO, 1988). The triangular test is a forced-choice procedure, which indicates whether or not a detectable difference exists between two samples. The assessors receive three cooked samples, are told that two of the samples are identical and one is different, and are asked to identify the odd sample.

\section{$\underline{\text { Statistical analysis }}$}

One-way ANOVA analysis was initially applied to evaluate the tank effect. Nevertheless, since the diet resulted to be not affected by the tank, we collected all the data from fish fed diet FM and all the data from fish fed the diet PP and we did a T-test analysis to assess the statistical difference between the dietary groups. However, because the large number of analyses performed we run independent statistical analysis for each single parameter.

As the malonaldehyde content was determined at different time after the death, the statistical analysis model for this parameter included the number of days of refrigerated storage. As colour measurement was made in different sites of the fillet and of the skin at different time after death, the colour parameters at each site of measurement were analysed by a one-way ANOVA (diet) including in the model the days of refrigerated storage. Analysis of results from the triangular test obtained in each session (at the days 
3 and 7) is done by comparing the number of correct identifications with the number you would expect to obtain by chance alone. In order to test this, the number of correct identifications is compared to the number expected by use of a statistical table (Roessler et al., 1948).

\section{Results}

Growth trial and body traits

The observed mortality rate was exactly the same in both dietary treatments $(17 \%$ per each diet).

Changes in mean body weights of both groups over the entire period of the feeding trial are presented in Fig. 1. The growth performances of the two groups of sea bream are reported in Table 3. Both groups had similar weight gains and specific growth rates. Feed intake was higher in sea bream fed diet FM (0.48 vs $0.44 ; \mathrm{P}<0.01)$, while feed efficiency and protein efficiency ratio were significantly $(\mathrm{P}<0.01)$ higher in PP sea bream ( 0.83 vs 0.77 and 2.0 vs 1.76 , respectively).

The two groups of sea bream reached a similar final body weight ( 429 g FM vs $425 \mathrm{~g}$ PP) and no difference resulted for most of the other morphological-commercial traits except for the higher HSI $(0.87$ vs $0.80 \% ; \mathrm{P}<0.05)$ and the lower fillet with skin yields (45 vs $46 \%$; $\mathrm{P}<0.05$ ) observed in PP diet fed sea bream compared to those fed diet FM (Table 4).

\section{Chemical composition}

The whole body composition was similar between the two sea bream groups and no differences were observed (Table 3). With regard to the fillet composition (Table 4), fish fed diet FM showed higher value of moisture (696 vs $682 \mathrm{~g} \mathrm{~kg}^{-1}$ ) while those fed diet PP had a higher level of total lipids and cholesterol (100 vs $91 \mathrm{~g} \mathrm{~kg}^{-1}$ and $0.80 \mathrm{vs}$ 
$0.76 \mathrm{~g} \mathrm{~kg}^{-1}$, respectively). The average malonaldehyde content evaluated during the shelf-life did not differ between the dietary groups (Table 4).

The only difference observed in liver composition between the two groups was the total lipid content, higher in PP sea bream (176 vs $143 \mathrm{~g} \mathrm{~kg}^{-1}$ ). The fatty acid composition expressed as percentage of total fatty acids of fresh muscle (Table 5) showed significant differences between FM and PP groups: monounsaturated (MUFA), polyunsaturated n-3 (n-3 PUFA) fatty acids and the n-3/n-6 ratio were significantly higher $(\mathrm{P}<0.01)$ in sea bream fed FM diet, while polyunsaturated n-6 (PUFA n-6) fatty acids were significantly higher in sea bream fed PP diet $(9.8$ vs $4.0 \% ; \mathrm{P}<0.01)$ and no differences were observed in total saturated fatty acid (SFA) content. There was a higher level of linoleic acid in PP sea bream fillet ( 8.5 vs $2.9 \%$ ), while fillet from sea bream fed diet FM had higher levels of eicosapentaenoic and docosahexaenoic acids (6.7 vs 5.4, and 12.6 vs $10.4 \%$, respectively). Expressed as g/100g, less differences were observed, but the level of n-6 PUFA was confirmed to be higher in PP fed sea bream, which also had a higher content of SFA, but the MUFA and the n-3 PUFA levels did not differ between the dietary groups. FM fed sea bream showed better thrombogenicity index of fillet lipid than PP ones. As regards liver fatty acid composition expressed as percentage of total fatty acids (Table 6), the sea bream fed diet FM had higher level of n-3 PUFA respect to the PP sea bream which had higher proportions of SFA and n-6 PUFA. No differences were found for the MUFA level between the two groups. Expressed per weight unit of tissue, there were no differences between groups for the hepatic n-3 PUFA levels.

Data on muscle free amino acid levels indicated some differences (Table 7). At death, muscle from sea bream fed diet PP had higher levels of threonine, glutamic acid, alanine, leucine and lysine and a lower level of ornithine than the muscle from FM-fed fish. The main differences observed were for threonine, glutamic acid, leucine and lysine (about 2 times higher in PP fish). At 11 days post-mortem, differences in the 
same sense were confirmed for glutamic acid, alanine, lysine and ornithine; PP sea bream also showed higher values of asparagine and glycine. The main differences came out for lysine and glycine (in PP fish 1.9 and 2.4 higher than in FM fish, respectively). The sum of free amino acids did not differ at the time of slaughter but was higher in the muscle of PP-fed sea bream after 11 days of refrigerated storage.

\section{$\underline{\text { Instrumental colour measurement }}$}

The colour measurement resulted in few differences (table 8). As regard as the skin colour the opercular site presented higher levels of $\mathrm{L}^{*}$ and $\mathrm{a}^{*}$ in sea bream fed diet FM. Also in the abdominal site, the $\mathrm{L}^{*}$ value was higher in this group. Sea bream fed diet PP had higher values of $b^{*}$ in the abdominal and rostral site. The fillets showed similar characteristics of colour, the only difference was the higher value of lightness in the cephalic epaxial site of the fillets from PP-fed sea bream.

\section{$\underline{\text { Sensory evaluation }}$}

The judges were unable to recognise the fillets from the two groups. Both at 3 and 7 days of refrigerated storage, the correct answers were only $50 \%$ and $39 \%$, respectively with no statistical difference between the FM and PP fillets.

\section{Discussion}

This is the first ever study over such a long duration under controlled conditions, to produce market size sea bream for quality analysis, making comparisons with earlier studies of shorter duration rather difficult. The higher feed intake observed in sea bream fed diet FM with respect to those fed diet based on $75 \%$ plant proteins, differs from data obtained by Robaina et al. (1995), who did not find any difference in feed intake of sea bream fed diets with different levels of plant protein sources over two months. The 
lower feed intake with diet PP could be due to lower palatability of this feed as also suggested by the data of Pereira and Oliva-Teles (2002). However, what is important is that the values of PER and FE were higher in this group, suggesting better utilisation of this feed with the final outcome being similar weight gains as well as daily nitrogen and fat gains in both groups (Table 3). These data are consistent with data of GomezRéqueni et al. (2004) in juvenile sea bream (average final body weight $70 \mathrm{~g}$ ) fed the same diets over 81 days. Combined together, these data indicate that plant protein diet induced similar effects on parameters of feed and nutrient utilisation both in juveniles and in commercial size sea bream.

On the other hand, the obtained specific growth rate in both group $(0.4 \%)$ was lower if compared with the literature. Nevertheless it is worth to note that we performed a long duration trial (one year) and that we reared sea bream under natural water temperature condition, so that it is impossible to compare our data with the previous studies. Pereira and Oliva Teles (2002), obtained a specific growth rate higher than $1.6 \%$ in sea bream feeding increasing level of pea seed meal for 12 weeks, with a constant temperature $\left(21^{\circ} \mathrm{C}\right)$. Gomes-Requeni et al. (2004), reported (in a study by the same group as those submitting the present manuscript with the same diets) a specific growth rate higher than $1.7 \%$ on sea bream during early stage of growth, for 12 weeks (temperature ranging from 17 to $25^{\circ} \mathrm{C}$ ).

The same final body weight of sea bream at the end of the growth trial is an important finding, as many earlier studies have shown a decrease in growth performance in marine fish fed diets containing high levels of plant protein sources. Inclusion of plant protein up to $30 \%$ does not seem to affect growth in different marine species, such as gilthead sea bream, turbot or European sea bass (Robaina et al., 1995, 1997; Burel et al., 2000; Kissil et al., 2000). Sea bream fed soybean or rapeseed protein concentrates at $60 \%$ of inclusion reached a final body weight lower respect to the control fed a fish meal diet 
(Kissil et al., 2000). In the same way turbot reared with diet containing $46 \%$ of rapeseed, reached a final body weight significant lower respect to the control (Burel et al., 2000). In tune with our data, Kaushik et al. (2004) also did not observe any negative effect on growth performance or nutrition utilisation in European sea bass fed a diet containing $98 \%$ of plant protein sources.

It is also encouraging to note that inclusion of high levels of plant protein sources did not affect morphological and body traits, except for the percentage of the fillets with skin, higher in sea bream fed diet FM, and for the HSI which was slightly but significantly higher in sea bream fed diet PP. Kaushik et al. (2004) did not observe any effect of the protein source in the HSI value of reared sea bass fed diet high levels of plant ingredients.

Different and contrasting results are reported in the literature regarding the effect of plant protein sources on fat content in reared fish. No effects on whole fat content were observed on salmonids (Carter and Hauler, 2000) and sea bream (Pereira and Oliva Teles, 2002) fed diets containing plant meals. However others researches reported an augmentation of lipid content in trout fed a diet containing 50\% of extruded lupin (Burel et al., 2000) and in sea bass (Kaushik et al., 2004) fed diets with increasing level of fish meal replacement by plant proteins. Opposite results were obtained by Robaina et al., (1998) in sea bream, and by Kissil et al, (2000) in sea bass, both reported a decrease in body fat for fish fed plant proteins. In the present trial no difference emerged between FM and PP sea bream whole body fat.

Concerning the fillet chemical composition, ours data on lipids content are consistent with values reported by Alasalvar et al. (2002) for farmed sea bream of $400 \mathrm{~g}$ body weight. The effect of vegetal protein sources on fat in different reared fish, is still under investigations and it is probably related to a different lipid metabolism and to the different protein sources. 
In spite of the clear differences in dietary cholesterol levels $\left(2.0\right.$ and $1.2 \mathrm{~g} \mathrm{~kg}^{-1}$ in the FM and PP diets, respectively), only the hepatic level showed a similar tendency, while in the muscle slightly higher cholesterol was found in fish fed PP diet. We hypothesize a negative feed-back induced in FM sea bream by the high dietary cholesterol content, but further studies are warranted to understand tissue cholesterol homeostasis, poorly investigated in fish.

In earlier studies with total fish meal substitution (Kaushik et al., 1995; 2004; Watanabe et al. 1998), the possible effects on fatty acid composition have not been looked into. The different fatty acid profile observed in the two dietary groups reflected the fatty acid composition of the diets, as reported abundantly in several fish including gilthead sea bream (Watanabe et al., 1982; Sargent et al., 2002; Izquierdo et al., 2003). Although the PP diet was supplemented with fish oil, there were differences in the fatty acid profile; especially there was a high level of 18:2 n-6 and a slight reduction in EPA and DHA (Table 2). As in most fish, the fillet fatty acid composition reflected that of the diet. Sea bream fed diet PP in which $75 \%$ of fish meal was substituted by plant protein sources, had a higher percentage of n-6 PUFA and lower levels of MUFA and n-3 PUFA. The fatty acids values obtained in this trial (expressed as percentage of total fatty acids of fresh muscle) are much higher compared to data from sea bream fed vegetable oils in partial replacement of fish oil (Izquierdo et al., 2003). At the quantitative level, the sum of EPA and DHA in the muscle of sea bream was 1.4 and 1.3 g / $100 \mathrm{~g}$ fillet in FM and PP groups (Table 5). This result is of importance given the beneficial effects of these fatty acids, especially with regard to cardio-vascular disease prevention in humans (Sidhu, 2003; Thies et al., 2003). The fillet fatty acids content observed in this trial for both group is above the recommended daily intake of $0.65 \mathrm{~g}$ of EPA + DHA reported by Simopoulos (1999). However, the International Society for the Study of Fatty Acids and Lipids (ISSFAL, 2004) recently suggested a minimum weakly 
intake of eicosapentaenoic acid (EPA) and docosahexaenoic acid (DHA) combined of $3.5 \mathrm{~g}$, for cardiovascular health. According to this, it should be recommended to eat approximately $270 \mathrm{~g}$ of fish fillet every week.

The malonaldehyde content as observed here was higher than data reported in the literature for marine sparids. Poli et al. (1998) observed a malonaldehyde value of 0.67 $\mathrm{mg} / \mathrm{kg}$ in sea bream of similar size. Likewise, for European sea bass a malonaldehyde level of $0.41 \mathrm{mg} / \mathrm{kg}$ at the $9^{\text {th }}$ day of refrigerated $\left(4{ }^{\circ} \mathrm{C}\right)$ storage with ice covering (Poli et al., 2001) was reported.

The slightly higher levels of free amino acids in the muscle of sea bream fed the diet PP both at slaughter and after 11 days of refrigerated storage, is probably due to the addition of synthetic amino acids in the diet, but do not really correspond to the individual amino acid patterns. However, such differences do not seem to be reflected on the organoleptic quality of the fillets. Further studies on biogenic amines might show more light. Despite a relatively high level of corn gluten meal in the diet PP $(180 \mathrm{~g} / \mathrm{kg})$, only minor differences were observed in the colour characteristics of the two dietary groups, mostly in the skin sites. This is contrary to the observations of Robaina et al. (1997) who reported a yellow-orange colour in operculum and fins in juvenile gilthead sea bream ( $80 \mathrm{~g}$ ) fed diets containing increasing levels (10 to $21 \%$ ) of corn gluten meal. In the salmonids, dietary corn gluten meal has a notable effect on fillet colour (Hardy, 1996; Dias, 1999; de Francesco et al., 2004).

The evaluation of sensory quality carried out at the $3^{\text {rd }}$ and $7^{\text {th }}$ day after the refrigerated storage by a triangular test could not discriminate the different dietary groups, despite the observed differences in the chemical composition, related to lipid, fatty acid and free amino acid content. This is probably not surprising since even big changes in flesh fatty acid profiles do not seem to induce any big changes in sensory response of cooked fillets of sea bream (Izquierdo et al., 2003). 
In conclusion, our results demonstrate the possibility to use diets containing high percentage $(75 \%)$ of plant ingredients in gilthead sea bream, with equivalent growth performance and with little effects on quality traits of the commercial product.

\section{Acknowledgements}

The authors thank Antonio Bonelli and Jeannine Brèque for their technical support, and the staff of the CSIC (Institut of Aquaculture, Torre de la Sal, Spain) Experimental Fish Farm for the care of the fish. This research was supported by the European project QLRT-1999-30068 "Perspectives of plant protein use in aquaculture". 


\section{References}

Alasalvar, C., Taylor, D.A.K. \& Shahidi, F. (2002) Comparative quality assessment of cultured sea bream (Sparus aurata) stored in ice. J. Agricultural and Food Chemistry, 50, 2039-2045.

A.O.A.C. (1990) Official Methods of Analysis of the Association of Official Analytical Chemists In: Heldrich, K. (Ed.),. AOAC, Arlington, VA, 684 pp.

A.O.A.C. (1995) Official Methods of Analysis of the Association of the Official Analysis Chemists, Association of Official Analytical Chemists, Arlington, VA, USA.

Aoki, H., Shimazu, H., Fukushige, T., Akano, H., Yamagata, Y. \& Watanabe, T. (1996) Flesh quality in red sea bream fed with diet containing a combination of different protein sources as total substitution for fish meal. Bull. Fish. Res. Inst. Mie., 6, 47-54.

Burel, C., Boujard, T., Tulli, F., Kaushik, S.J. (2000) Digestibility of extruded peas, extruded lupin, and rapeseed meal in rainbow trout (Oncorhynchus mykiss) and turbot (Psetta maxima). Aquaculture, 188, 285-298.

Carter, C.G. \& Hauler, R.C. (2000) Fish meal replacement by plant meals in extruded feeds for Atlantic salmon, Salmo salar L. Aquaculture, 185, 299-311

CIE (Commission Internationale de L'Eclairage) (1976) Colorimetry. Pub. $\mathrm{N}^{\circ}$ 15, Bureau Central de la CIE, Vienna, Austria.

Dias, J. (1999) Lipid deposition in rainbow trout (Oncorhynchus mykiss) and European sea bass (Dicentrarchus labrax): Nutritional control of hepatic lipogenesis. PhD Thesis, Univ. Porto, Portugal \& Univ. Bordeaux I, France: 190 p.

de Francesco, M., Parisi, G., Médale, F., Lupi, P., Kaushik, S.J. \& Poli, B.M. (2004) Effect of long-term feeding with a plant protein mixture based diet on growth and 
body/fillet quality traits of large rainbow trout (Oncorhynchus mykiss). Aquaculture, 236, 413-429.

FAO (2001) Report of the Conference on Aquaculture in the Third Millennium. Bangkok, Thailand, 20-25 February 2000. FAO Fish. Rep. No. 661, 92 p.

FAO (2003) Fishery Statistics. Aquaculture production. Vol. 92/2.

Folch, J., Lees, M. \& Sloane-Stanley, G.H. (1957) A simple method for the isolation and purification of total lipids from animal tissues. J. Biol. Chem., 226, 497-509.

Francis, G., Makkar, P.S. \& Becker, K. (2001) Antinutritional factors present in plantderived alternate fish feed ingredients and their effects in fish. Aquaculture, 199, 197-227.

Geri, G., Gualtieri, M., Lupi, P., Parisi, G., Dell'Agnello, M. \& Mecatti, M. (1994) Evolution morphologique des téléostéens pendant la croissance: 1. Proposition d'une méthode d'étude. In: Metrology and Instrumentation in Aquaculture Management Measures for Success (Kestemont, P., Muir, J., Sévila, F., Williot, P. Eds.), Proceedings of Bordeaux Aquaculture '94, 23-25 March 1994, Bordeaux, France, CEMA-GREF Editions, Gap, France, pp. 239-243.

Gómez-Requeni P., Mingarro, M., Calduch-Giner, J.A., Médale, F., Martin, S.A.M, Houlihan, D.F., Kaushik, S.J. \& Pérez-Sánchez, J. (2004) Protein growth performance, amino acid utilisation and somatotropic axis responsiveness to fish meal replacement by plant protein sources in gilthead sea bream (Sparus aurata). Aquaculture, 232, 493-510.

Gouveia, A. \& Davies, S.J. (2000) Inclusion of an extruded dehulled pea seed meal in diets for juvenile European sea bass (Dicentrarchus labrax). Aquaculture, 182, 183-193.

Hardy, R.W. (1996) Alternate protein sources for salmon and trout diets. Anim. Feed Sci. Techn., 59, 71-80. 
I.S.S.F.A.L. (2004) Study of Fatty Acids and Lipids. Recommendations for intake of polyunsaturated fatty acids in healthy adults. June 2004

ISO, 1983. 4120-1983. Sensory analysis - Triangular test. International Organization for Standardization. Geneva, Switzerland.

ISO, 1988. 8589-1988. Sensory analysis - General guidance for the design of test rooms. International Organization for Standardization. Geneva, Switzerland.

Izquierdo, M. S., Obach, A., Arantzamendi, L., Montero, D., Robaina, L. \& Rosenlund, G. (2003) Dietary lipid sources for seabream and seabass: growth performance, tissue composition and flesh quality. Aquaculture Nutrition, 9, 397-407.

Kaushik, S.J. (1990) Use of alternative protein sources for the intensive rearing of carnivorous fishes. In: Mediterranean Aquaculture (R. Flos, L. Tort \& P. Torres, Eds), Ellis Horwood, UK. pp 125-138.

Kaushik, S.J., Cravedi, J.P., Lalles, J.P., Sumpter, J., Fauconneau, B. \& Laroche, M. (1995) Partial or total replacement of fish meal by soybean protein on growth, protein utilization, potential estrogenic or antigenic effects, cholesterolemia and flesh quality in rainbow trout (Oncorhynchus mykiss). Aquaculture, 133, 257274.

Kaushik, S.J., Covès, D., Dutto, G. \& Blanc, D. (2004) Almost total replacement of fish meal by plant protein sources in the diet of a marine teleost, the European seabass, Dicentrarchus labrax. Aquaculture, 230, 391-404.

Kissil, G.W., Lupatsch, I., Higgs, D.A. \& Hardy, R.W. (2000) Dietary substitution of soy and rapeseed protein concentrates for fish meal, and their utilization in gilthead seabream Sparus aurata L. Aquaculture Research, 31, 595-601.

Moore S. \& Stein, W.H. (1951) Chromatography of amino acids on sulfonated polystyrene resins. J. Biol. Chemistry, 192, 663-681. 
Morrison, R. \& Smith, M. L., (1964). Preparation of fatty acid methyl esters and dimethylacetals from lipids with boron fluoride-methanol. J. Lipid Research, 5, 600-608.

New, M. B. \& Wijkstroem, U. N. (2002) Use of fishmeal and fish oil in aquafeeds. Further thoughts on the fishmeal trap. FAO Fish. Circ. No. 975, 61 p.

NRC (National Research Council), (1993) Nutrient Requirements of Fish. National Academy Press, Washington, DC.

Pereira, T.G. \& Oliva-Teles, A. (2002) Preliminary evaluation of pea seed meal in diets for gilthead sea bream (Sparus aurata) juveniles. Aquaculture Research, 33, 1183-1189.

Poli, B.M., Parisi, G., Lupi, P., Mecatti, M., Bonelli, A., Zampacavallo G., Gualtieri, M. \& Mascini, M. (1998) Qualitative traits and shelf life in Pagrus major x Dentex dentex hybrids stored at refrigerated conditions and comparison with European gilthead seabream (Sparus aurata). XXXIII International Symposium on New Species for Mediterranean Aquaculture, Alghero, 22-24 April, 1998. Pp. 329336.

Poli, B.M., Parisi, G., Zampacavallo, G., Mecatti, M., Lupi, P., Gualtieri \& M., Franci, O. (2001) Quality outline of European sea bass (Dicentrarchus labrax) reared in Italy: shelf life, edible yield, nutritional and dietetic traits. Aquaculture, 202, 303315.

Raharjo, S., Sofos, J.N. \& Schmidt, G.R. (1993) Solid-phase acid extraction improves thiobarbituric acid method to determine lipid oxidation. J. Food Sci., 58, 921924.

Robaina, L., Izquierdo, M.S., Moyano, F.J., Socorro, J., Vergara, J.M., Montero, D. \& Fernàndez-Palacios, H. (1995) Soybean and lupin seed meals as protein sources 
in diets for gilthead seabream (Sparus aurata): nutritional and histological implications. Aquaculture, 130, 219-233.

Robaina, L., Moyano, F.J., Izquierdo, M.S., Socorro, J., Vergara, J.M. \& Montero D. (1997) Corn gluten and meat and bone meals as protein in diets for gilthead seabream (Sparus aurata): nutritional and histological implications. Aquaculture, $157,347-359$.

Robaina, L., Izquierdo, M.S., Moyano, F.J., Socorro, J., Vergara, J.M. \& Montero D. (1998) Increase of the dietary n-3/n-6 fatty acid ratio and addition of phosphorus improves liver histological alterations induced by feeding diets containing soybean meal to gilthead seabream, Sparus aurata. Aquaculture, 161, 281-293.

Roessler, E. B.; Warren, J. \& Guymon, J.F. (1948) Significance in triangular taste tests. In Lanmond, E., Laboratory Methods for Sensory Evaluation of Food. Food Research Institute, Canada, 1977.

Sargent, J.R., Tocher, D.R. \& Bell, G.J. (2002) The lipids. In: Fish Nutrition (Halver, J.E., Hardy, R. Eds.)., 3rd edn, pp. 181-257. Academic Press, San Diego, CA, USA.

Sidhu, K.S. (2003) Health benefits and potential risks related to consumption of fish or fish oil. Regulatory Toxicology and Pharmacology, 38, 336 -344.

Simopoulos, A.P., Leaf, A. \& Salem, N. (1999) Workshop on the essentiality of and recommended dietary intakes for omega- 6 and omega-3 fatty acids. $J$ Am Coll Nutr., 18, 487-489.

Storebakken, T., Shearer, K.D. \& Roem, A.J. (2000) Growth, uptake and retention of nitrogen and phosphorus, and absorption of other minerals in Atlantic salmon Salmo salar fed diets with fish meal and soy-protein concentrate as the main sources of protein. Aquaculture Nutrition, 6, 103-108. 
Tacon, A.G.J. (1997) Fishmeal replacers: Review of antinutrients within oilseeds and pulses. A limiting factor for the aquafeed green revolution? In: Feeding tomorrow's fish. Proc. Workshop of the CIHEAM Network on Technology of Aquaculture in the Mediterranean (TECAM), CIHEAM, FAO and IEO, Mazarron (Spain), Cah. Options Mediterr., 22, 153-182.

Tacon, A.G.J. \& Forster, I.P. (2003) Aquafeeds and the environment: policy implications. Aquaculture, 226, 181-189.

Thies, F., Garry, J.M.C., Yaqoob, P., Rerkasem, K., Williams, J., Shearman, C., Gallagher, P.J., Calder, P.C. \& Grimble, F.R. (2003) Association of n-3 polyunsatured fatty acids with stability of atherosclerotic plaques: a randomised controlled trial. The Lancet, 361, 477-485.

Ulbricht T.L.V. \& Southgate D.A.T. (1991) Coronary hearth disease: seven dietary factors. The Lancet, 338, 985-992.

Watanabe, T. (1982) Lipid nutrition in fish. Comp. Biochem. Physiol., 73 B, 3-15.

Watanabe, T., Verakunpiriya, V., Watanabe, K., Viswanath, K. \& Satoh, S. (1998) Feeding of rainbow trout with non-fish meal diets. Fisheries Sci., 63, 258-266. 
Table 1. Ingredients and chemical composition of the experimental diets.

\begin{tabular}{lcc}
\hline Ingredients $\left(\mathrm{g} \mathrm{kg}^{-1}\right)$ & $\mathrm{FM}$ & $\mathrm{PP}$ \\
\hline Fish meal, LT (CP 70\%) & 703.7 & 176.0 \\
Corn gluten meal & 0 & 180.0 \\
Wheat gluten & 0 & 180.0 \\
Extruded peas (Aquatex, France) & 0 & 90.0 \\
Rapeseed meal (Primor 00, France) & 0 & 67.2 \\
Extruded whole wheat & 142.0 & 30.6 \\
Fish oil & 124.3 & 149.8 \\
Binder (Na Alginate) & 10.0 & 10.0 \\
Mineral premix & 10.0 & 10.0 \\
Vitamin premix & & 10.0 \\
CaHPO $_{4} .2 \mathrm{H}_{2} 0(18 \% \mathrm{P})$ & 10.0 & 10.0 \\
${\text { Amino acid } \text { mix }^{3}}$ & 0 & 30.7
\end{tabular}

\section{Proximate composition}

Dry matter $\left(\mathrm{g} \mathrm{kg}^{-1}\right) \quad 904 \quad 896$

Crude Protein $\left(\mathrm{g} \mathrm{kg}^{-1} \mathrm{DM}\right) \quad 437 \quad 415$

Lipids ( $\left.\mathrm{g} \mathrm{kg}^{-1} \mathrm{DM}\right) \quad 162 \quad 177$

Gross energy ( $\left.\mathrm{k} \mathrm{Jg}^{-1} \mathrm{DM}\right) \quad 19.2 \quad 19.3$

${ }^{1}$ Supplied the following (mg/kg diet, except as noted): calcium carbonate $(40 \% \mathrm{Ca}) 2.15 \mathrm{~g}$, magnesium hydroxide $(60 \% \mathrm{Mg}) 1.24 \mathrm{~g}$, potassium chloride $0.9 \mathrm{~g}$, ferric citrate $0.2 \mathrm{~g}$, potassium iodine $4 \mathrm{mg}$, sodium chloride $0.4 \mathrm{~g}$, calcium hydrogen phosphate $50 \mathrm{~g}$, copper sulphate 0.3 , zinc sulphate 40 , cobalt sulphate 2 , manganese sulphate 30 , sodium selenite 0.3 .

${ }^{2}$ Supplied the following ( $\mathrm{mg} \mathrm{kg}^{-1}$ diet): retinyl acetate 2.58, DL-cholecalciferol 0.037, DL- $\alpha$ tocopheryl acetate 30 , menadione sodium bisulphite 2.5 , thiamin 7.5 , riboflavin 15 , pyridoxine 7.5 , nicotinic acid 87.5 , folic acid 2.5 , calcium pantothenate 2.5 , vitamin $B_{12} 0.025$, ascorbic acid 250, inositol 500, biotin 1.25 and choline chloride 500 .

${ }^{3}$ Amino acids $\mathrm{g} \mathrm{kg}^{-1}$ : L-Arg: 11.3; L-His: 3.4; L-Lys: 23.6; Dl-Met: 3.6;L-Trp: 2.2; L-Thr: 7.4; L-Ile: 6.2. 
Table 2 . Total lipids ${ }^{1}\left(\%\right.$ on wet weight), fatty $\operatorname{acids}^{2}(\%$ of total fatty acids) and cholesterol in the FM and PP experimental diets fed to sea bream.

\begin{tabular}{|c|c|c|}
\hline & FM & $\mathrm{PP}$ \\
\hline Total lipids \% & 18.2 & 17.3 \\
\hline \multicolumn{3}{|l|}{ Fatty acids $\%$} \\
\hline C14:0 & 6.5 & 5.2 \\
\hline C16:0 & 15.7 & 17.3 \\
\hline C16:1 n-7 & 4.8 & 4.7 \\
\hline C18:0 & 2.0 & 2.2 \\
\hline C18:1 n-9 & 16.4 & 22.0 \\
\hline C18:2 n-6 & 2.3 & 8.2 \\
\hline C18:3 n-3 & 1.5 & 2.2 \\
\hline C18:4 n-3 & 3.3 & 2.4 \\
\hline C20:1 n-9 & 8.1 & 4.6 \\
\hline$C 20: 5 n-3$ & 10.2 & 8.7 \\
\hline $\mathrm{C} 22: 1 \mathrm{n}-11$ & 12.1 & 7.0 \\
\hline$C 22: 6 n-3$ & 12.0 & 10.6 \\
\hline$\Sigma$ SFA & 24.9 & 25.6 \\
\hline$\Sigma$ MUFA & 44.0 & 39.0 \\
\hline$\Sigma$ PUFA n-6 & 3.4 & 9.4 \\
\hline$\Sigma$ PUFA n-3 & 28.8 & 25.6 \\
\hline PUFA n-3/PUFA n-6 & 8.5 & 2.7 \\
\hline Cholesterol $\left(\mathrm{g} \mathrm{kg}^{-1}\right)$ & 2.03 & 1.2 \\
\hline
\end{tabular}

\footnotetext{
${ }^{1}$ The total lipids content was determined by Folch et al. (1957)

${ }^{2}$ The fatty acids C12:0, C14:1 n-5, C15:0, C16:2 n-4, C17:0, C16:3 n-3, C16:4 n-1, C18:2 n-4, C18:3 n-6, C18:3 n-4, C20:0, C20:1 n-7, C20:2 n-6, C20:3 n-3, C20:3 n-6, C20:4 n-6, C21:5 n-3, C22:4 n-6, C22:5 $\mathrm{n}-6$, in percentage less than $1 \%$, were considered in the composite fractions but not reported in the table for brevity.
} 
Table 3. Growth performance, feed intake and feed efficiency of sea bream fed the FM and PP $\operatorname{diets}^{1}$.

\begin{tabular}{|c|c|c|}
\hline & $\begin{array}{c}\mathrm{FM} \\
(\mathrm{n}=120)\end{array}$ & $\begin{array}{c}\mathrm{PP} \\
(\mathrm{n}=120)\end{array}$ \\
\hline Initial body weight (IBW) (g) & $99.1 \pm 0.3$ & $99.7 \pm 0.3$ \\
\hline Final body weight $(\mathrm{FBW})(\mathrm{g})$ & $431.4 \pm 1.1$ & $427.1 \pm 1.1$ \\
\hline Feed intake (\% BW/day) & $0.48 \pm 0.01^{\mathrm{A}}$ & $0.44 \pm 0.01^{\mathrm{B}}$ \\
\hline Weight gain $(\%)$ & $335.5 \pm 1.2$ & $328.2 \pm 1.2$ \\
\hline 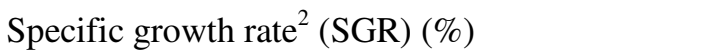 & $0.44 \pm 0.01$ & $0.43 \pm 0.01$ \\
\hline Feed efficiency ${ }^{3}(\mathrm{FE})$ & $0.77 \pm 0.01^{\mathrm{B}}$ & $0.83 \pm 0.01^{\mathrm{A}}$ \\
\hline Protein efficiency ratio ${ }^{4}$ (PER) & $1.76 \pm 0.01^{\mathrm{B}}$ & $2.00 \pm 0.01^{\mathrm{A}}$ \\
\hline Final whole body chemical composition ${ }^{5}\left(\mathrm{~g} \mathrm{~kg}^{-1}\right)$ & $(\mathrm{n}=10)$ & $(\mathrm{n}=10)$ \\
\hline Moisture & $615 \pm 4$ & $613 \pm 5$ \\
\hline Protein & $172 \pm 2$ & $173 \pm 1$ \\
\hline Lipids & $148 \pm 2$ & $151 \pm 3$ \\
\hline Daily N gain (mg/kg BW/day) & $103.3 \pm 1.9$ & $103.4 \pm 0.7$ \\
\hline Daily Fat gain (g/kg BW/day) & $0.60 \pm 0.01$ & $0.61 \pm 0.02$ \\
\hline
\end{tabular}

${ }^{\mathrm{T}}$ Each value is the mean \pm SEM of duplicate tanks. Different superscript letters in the same row indicate significant statistical differences $(\mathrm{A}, \mathrm{B}: \mathrm{P}<0.01)$

${ }^{2}$ Specific growth rate $=[100 \mathrm{x}(\ln \mathrm{FBW}-\ln \mathrm{IBW})] /$ days.

${ }^{3}$ Feed efficiency $=$ wet weight gain $/$ dry feed intake.

${ }^{4}$ Protein efficiency ratio $=$ wet weight gain $/$ crude protein intake.

${ }^{5}$ Initial whole body composition: moisture $663 \mathrm{~g} \mathrm{~kg}^{-1}$; protein $163 \mathrm{~g} \mathrm{~kg}^{-1}$; lipids $102 \mathrm{~g} \mathrm{~kg}^{-1}$ 
Table 4. Body morphological traits, fillet and liver chemical composition (on wet weight basis) in sea bream fed the FM or PP diets ${ }^{1}$.

\begin{tabular}{|c|c|c|c|c|c|}
\hline & $\mathrm{n}$ & FM & $\mathrm{n}$ & $\mathrm{PP}$ & rsd \\
\hline \multicolumn{6}{|l|}{ Morphometric data } \\
\hline Body weight $^{2}$ (g) & 100 & 428.8 & 100 & 425.4 & 49.6 \\
\hline Total length (cm) & 100 & 28.2 & 100 & 28.0 & 1.12 \\
\hline Standard length $(\mathrm{cm})$ & 100 & 23.5 & 100 & 23.5 & 1.89 \\
\hline Condition factor & 100 & 1.90 & 100 & 1.94 & 0.47 \\
\hline Agility index & 54 & 2.05 & 54 & 2.04 & 0.15 \\
\hline Cranial index & 54 & 0.23 & 54 & 0.23 & 0.003 \\
\hline Relative profile & 54 & 0.34 & 54 & 0.34 & 0.006 \\
\hline \multicolumn{6}{|l|}{ Body components } \\
\hline Fins $(\%)$ & 63 & 6.9 & 63 & 6.8 & 0.19 \\
\hline Gills (\%) & 66 & 2.2 & 66 & 2.2 & 0.25 \\
\hline Head $(\%)$ & 66 & 26.2 & 66 & 26.2 & 2.93 \\
\hline Hepato-somatic index ${ }^{3}$ (HSI, \%) & 88 & $0.80 \mathrm{~b}$ & 88 & $0.87 \mathrm{a}$ & 0.22 \\
\hline Digestive tract (\%) & 66 & 1.7 & 66 & 1.6 & 0.37 \\
\hline Mesenteric fat (\%) & 66 & 2.76 & 66 & 2.90 & 1.05 \\
\hline Visceral index ${ }^{4}$ (VSI, \%) & 66 & 6.03 & 66 & 6.21 & 1.10 \\
\hline \multicolumn{6}{|l|}{ Commercial traits } \\
\hline Dressing $(\%)$ & 66 & 93.97 & 66 & 93.79 & 1.10 \\
\hline Fillets with skin (\%) & 88 & $45.92^{\mathrm{a}}$ & 88 & $44.94^{\mathrm{b}}$ & 3.20 \\
\hline \multicolumn{6}{|l|}{ Fillet composition $\left(\mathrm{g} \mathrm{kg}^{-1}\right)$} \\
\hline Moisture & 30 & $696^{\mathrm{A}}$ & 30 & $682^{\mathrm{B}}$ & 16.7 \\
\hline Crude protein & 12 & 182 & 12 & 183 & 14.2 \\
\hline Total lipids & 30 & $91^{b}$ & 30 & $100^{\mathrm{a}}$ & 16.1 \\
\hline Ash & 12 & 14 & 12 & 14 & 1.3 \\
\hline Phosphorus & 12 & 1.9 & 12 & 1.9 & 0.20 \\
\hline Cholesterol & 30 & $0.76^{\mathrm{B}}$ & 30 & $0.80^{\mathrm{A}}$ & 0.173 \\
\hline Malonaldehyde (mg/kg) & 18 & 1.37 & 18 & 1.05 & 0.50 \\
\hline \multicolumn{6}{|l|}{ Liver composition ${ }^{5}\left(\mathrm{~g} \mathrm{~kg}^{-1}\right)$} \\
\hline Moisture & 8 & 636 & 8 & 600 & 25.3 \\
\hline Crude protein & 8 & 157 & 8 & 147 & 9.8 \\
\hline Total lipids & 8 & $143^{\mathrm{b}}$ & 8 & $176^{\mathrm{a}}$ & 25.1 \\
\hline Ash & 8 & 12 & 8 & 11 & 1.6 \\
\hline Phosphorus & 8 & 2.0 & 8 & 2.3 & 0.60 \\
\hline Cholesterol & 8 & 1.32 & 8 & 1.24 & 0.102 \\
\hline
\end{tabular}

\footnotetext{
${ }^{\mathrm{T}}$ Means are indicated with residual standard deviation (rsd). Different superscript letters in the same row indicate significant differences $(\mathrm{a}, \mathrm{b}: \mathrm{P}<0.05$; $\mathrm{A}, \mathrm{B}: \mathrm{P}<0.01)$.

${ }^{2}$ Value obtained by the fish individually weighed.

${ }^{3} \mathrm{HSI}=[100 \mathrm{x}$ (liver weight/body weight) $]$

${ }^{4} \mathrm{VSI}=[100 \mathrm{x}$ (total viscera weight/body weight) $]$

${ }^{5}$ For the analysis of liver, each analysed sample has been obtained grouping livers of three different animals.
} 
Table 5. Fatty acid composition of fillets of sea bream fed diets based on fish meal (FM) or on a mixture of plant protein sources $(\mathrm{PP})^{1}$.

\begin{tabular}{|c|c|c|c|c|c|c|}
\hline & $\begin{array}{c}\mathrm{FM} \\
(\mathrm{n}=30)\end{array}$ & $\begin{array}{c}\mathrm{PP} \\
(\mathrm{n}=30)\end{array}$ & rsd & $\begin{array}{c}\mathrm{FM} \\
(\mathrm{n}=30)\end{array}$ & $\begin{array}{c}\mathrm{PP} \\
(\mathrm{n}=30)\end{array}$ & rsd \\
\hline Fillet fatty acids ${ }^{2}$ & \multicolumn{2}{|c|}{$\%$ of total fatty acids } & \multicolumn{4}{|c|}{$\mathrm{g} / 100 \mathrm{~g}$ of fresh tissue } \\
\hline C14:0 & $5.54^{\mathrm{A}}$ & $4.36^{\mathrm{B}}$ & 0.17 & $0.415^{\mathrm{A}}$ & $0.356^{\mathrm{B}}$ & 0.06 \\
\hline $\mathrm{C} 16: 0$ & $16.53^{\mathrm{B}}$ & $17.41^{\mathrm{A}}$ & 0.52 & $1.238^{\mathrm{B}}$ & $1.448^{\mathrm{A}}$ & 0.23 \\
\hline C16:1 n-7 & $7.02^{\mathrm{A}}$ & $6.74^{\mathrm{B}}$ & 0.40 & 0.527 & 0.549 & 0.13 \\
\hline C18:0 & $2.27^{\mathrm{B}}$ & $2.67^{\mathrm{A}}$ & 0.16 & $0.169^{\mathrm{B}}$ & $0.222^{\mathrm{A}}$ & 0.03 \\
\hline C18:1 n-9 & $20.90^{\mathrm{B}}$ & $25.30^{\mathrm{A}}$ & 0.78 & $1.568^{\mathrm{B}}$ & $2.108^{\mathrm{A}}$ & 0.34 \\
\hline C18:2 n-6 & $2.92^{\mathrm{B}}$ & $8.47^{\mathrm{A}}$ & 0.27 & $0.219^{\mathrm{B}}$ & $0.702^{\mathrm{A}}$ & 0.08 \\
\hline C18:3 n-3 & $2.12^{\mathrm{B}}$ & $2.55^{\mathrm{A}}$ & 0.21 & $0.160^{\mathrm{B}}$ & $0.213^{\mathrm{A}}$ & 0.04 \\
\hline C18:4 n-3 & $2.18^{\mathrm{A}}$ & $1.51^{\mathrm{B}}$ & 0.07 & $0.164^{\mathrm{A}}$ & $0.126 \mathrm{~B}$ & 0.03 \\
\hline C20:1 n-9 & $7.09^{\mathrm{A}}$ & $4.39^{\mathrm{B}}$ & 0.23 & $0.530^{\mathrm{A}}$ & $0.363^{\mathrm{B}}$ & 0.07 \\
\hline C20:4 n-3 & $1.17^{\mathrm{A}}$ & $1.00^{\mathrm{B}}$ & 0.08 & 0.087 & 0.083 & 0.005 \\
\hline$C 20: 5 n-3$ & $6.72^{\mathrm{A}}$ & $5.36^{\mathrm{B}}$ & 0.21 & $0.502^{\mathrm{A}}$ & $0.444^{\mathrm{B}}$ & 0.08 \\
\hline $\mathrm{C} 22: 1 \mathrm{n}-11$ & $6.62^{\mathrm{A}}$ & $4.40^{\mathrm{B}}$ & 0.28 & $0.540^{\mathrm{A}}$ & $0.364^{\mathrm{B}}$ & 0.70 \\
\hline C22:1 n-9 & $1.044^{\mathrm{A}}$ & $0.73^{\mathrm{B}}$ & 0.03 & $0.078^{\mathrm{A}}$ & $0.060^{\mathrm{B}}$ & 0.003 \\
\hline$C 22: 5 n-3$ & 1.29 & 1.86 & 0.09 & 0.149 & 0.154 & 0.03 \\
\hline$C 22: 6 n-3$ & $12.59^{\mathrm{A}}$ & $10.44^{\mathrm{B}}$ & 0.52 & $0.939^{\mathrm{a}}$ & $0.862^{\mathrm{b}}$ & 0.13 \\
\hline SFA & 24.93 & 25.04 & 0.30 & $1.867^{\mathrm{b}}$ & $2.082^{\mathrm{a}}$ & 0.33 \\
\hline MUFA & $43.69^{\mathrm{A}}$ & $41.87^{\mathrm{B}}$ & 1.16 & 3.275 & 3.486 & 0.60 \\
\hline$\Sigma$ PUFA n-6 & $4.05^{\mathrm{B}}$ & $9.78^{\mathrm{A}}$ & 0.33 & $0.304^{\mathrm{B}}$ & $0.810^{\mathrm{A}}$ & 0.10 \\
\hline$\Sigma$ PUFA n-3 & $27.15^{\mathrm{A}}$ & $22.99^{\mathrm{B}}$ & 0.78 & 2.030 & 1.905 & 0.30 \\
\hline PUFA n-3/PUFA n-6 & $6.73^{\mathrm{A}}$ & $2.35^{\mathrm{B}}$ & 2.43 & & & \\
\hline Total & & & & $7.497^{\mathrm{b}}$ & $8.308^{\mathrm{a}}$ & 1.33 \\
\hline $\mathrm{AI}^{3}$ & & & & 1.566 & 1.545 & 0.26 \\
\hline $\mathrm{TI}^{4}$ & & & & $0.196^{\mathrm{B}}$ & $0.430^{\mathrm{A}}$ & 0.06 \\
\hline
\end{tabular}

${ }^{1}$ Means are indicated with residual standard deviation (rsd). Different superscript letters in the same row indicate significant statistical differences (a, b: $\mathrm{P}<0.05 ; \mathrm{A}, \mathrm{B}: \mathrm{P}<0.01)$.

${ }^{2}$ Fatty acids C12:0, C14:1 n-5, C15:0, C16:2 n-4, C17:0, C16:3 n-3, C16:4 n-1, C18:2 n-4, C18:3 n-6, C18:3 n-4, C20:0, C20:1 n-7, C20:2 n-6, C20:3 n-3, C20:3 n-6, C20:4 n-6, C21:5 n-3, C22:4 n-6, $\mathrm{C} 22: 5 \mathrm{n}-6$, in percentage less than $1 \%$, were considered in the composite fractions but not reported in the table for brevity.

\footnotetext{
${ }^{3}$ Atherogenicity index $=(\mathrm{C} 12: 0+4 * \mathrm{C} 14: 0+\mathrm{C} 16: 0) /($ PUFA n6+PUFA n3+MUFA $)$

${ }^{4}$ Thrombogenicity index $=($ C14:0+C16:0+C18:0)/[(0.5*PUFA n6 $)+\left(3^{*}\right.$ PUFA n3 $)+\left(0.5^{*}\right.$ MUFA $)+$ (PUFA n3/PUFA n6)]
} 
Table 6. Liver fatty acid composition of sea bream fed diets based on fish meal (FM) or on a mixture of plant protein sources $(\mathrm{PP})^{1}$.

\begin{tabular}{|c|c|c|c|c|c|c|}
\hline & $\mathrm{FM}(\mathrm{n}=8)$ & $P P(n=8)$ & rsd & $\mathrm{FM}(\mathrm{n}=8)$ & $P P(n=8)$ & rsd \\
\hline Liver fatty acids ${ }^{2}$ & \multicolumn{3}{|c|}{$\%$ of total fatty acids } & \multicolumn{3}{|c|}{$\mathrm{g} / 100 \mathrm{~g}$ of fresh tissue } \\
\hline C14:0 & $4.80^{\mathrm{A}}$ & $3.83^{\mathrm{B}}$ & 0.291 & 0.581 & 0.573 & 0.114 \\
\hline C16:0 & $19.29^{\mathrm{B}}$ & $20.86^{\mathrm{A}}$ & 0.876 & $2.308^{\mathrm{B}}$ & $3.120^{\mathrm{A}}$ & 0.450 \\
\hline C16:1 n-7 & 5.97 & 5.94 & 0.277 & $0.721^{\mathrm{b}}$ & $0.889^{\mathrm{a}}$ & 0.155 \\
\hline C18:0 & $3.68^{\mathrm{B}}$ & $4.75^{\mathrm{A}}$ & 0.516 & $0.437^{\mathrm{B}}$ & $0.711^{\mathrm{A}}$ & 0.114 \\
\hline C18:1 n-9 & $22.99^{\mathrm{B}}$ & $28.50^{\mathrm{A}}$ & 1.429 & $2.754^{\mathrm{B}}$ & $4.280^{\mathrm{A}}$ & 0.696 \\
\hline C18:2 n-6 & $2.28^{\mathrm{B}}$ & $7.03^{\mathrm{A}}$ & 0.400 & $0.275^{\mathrm{B}}$ & $1.052^{\mathrm{A}}$ & 0.145 \\
\hline C18:3 n-3 & $1.43^{\mathrm{B}}$ & $1.69^{\mathrm{A}}$ & 0.167 & $0.174^{\mathrm{B}}$ & $0.252^{\mathrm{A}}$ & 0.045 \\
\hline C18:4 n-3 & $1.63^{\mathrm{A}}$ & $1.07^{\mathrm{B}}$ & 0.173 & 0.197 & 0.160 & 0.045 \\
\hline C20:1 n-9 & $5.90^{\mathrm{A}}$ & $3.48^{\mathrm{B}}$ & 0.305 & $0.712^{\mathrm{A}}$ & $0.519^{\mathrm{B}}$ & 0.118 \\
\hline C20:4 n-3 & $1.20^{\mathrm{A}}$ & $0.91^{\mathrm{B}}$ & 0.055 & 0.144 & 0.136 & 0.032 \\
\hline$C 20: 5 n-3$ & $6.57^{\mathrm{A}}$ & $4.57^{\mathrm{B}}$ & 0.335 & 0.788 & 0.680 & 0.122 \\
\hline $\mathrm{C} 22: 1 \mathrm{n}-11$ & $5.53^{\mathrm{A}}$ & $2.73^{\mathrm{B}}$ & 0.400 & $0.669^{\mathrm{A}}$ & $0.408^{\mathrm{B}}$ & 0.118 \\
\hline$C 22: 5 n-3$ & 1.81 & 1.73 & 0.530 & 0.217 & 0.257 & 0.071 \\
\hline$C 22: 6 n-3$ & $13.20^{\mathrm{A}}$ & $9.86^{\mathrm{B}}$ & 0.713 & 1.579 & 1.461 & 0.207 \\
\hline$\Sigma$ SFA & $28.34^{\mathrm{B}}$ & $29.91^{\mathrm{A}}$ & 1.027 & $3.393^{\mathrm{B}}$ & $4.474^{\mathrm{A}}$ & 0.653 \\
\hline$\Sigma$ MUFA & 41.46 & 41.18 & 1.117 & $4.985^{\mathrm{b}}$ & $6.177^{\mathrm{a}}$ & 1.040 \\
\hline ¿PUFAn-6 & $3.71^{\mathrm{B}}$ & $8.56^{\mathrm{A}}$ & 0.454 & $0.446^{\mathrm{B}}$ & $1.276^{\mathrm{A}}$ & 0.161 \\
\hline sPUFAn-3 & $27.66^{\mathrm{A}}$ & $20.08^{\mathrm{B}}$ & 3.723 & 3.280 & 2.982 & 0.476 \\
\hline Total & & & & $12.002^{\mathrm{B}}$ & $14.948^{\mathrm{A}}$ & 2.230 \\
\hline PUFA n-3/PUFA n-6 & & & & $7.431^{\mathrm{A}}$ & $2.346^{\mathrm{B}}$ & 0.830 \\
\hline
\end{tabular}

${ }^{1}$ Means are indicated with residual standard deviation (rsd). Different superscript letters in the same row indicate significant statistical differences $(\mathrm{a}, \mathrm{b}: \mathrm{P}<0.05 ; \mathrm{A}, \mathrm{B}: \mathrm{P}<0.01)$.

${ }^{2}$ Each analysed sample has been obtained grouping the livers of three different fish

${ }^{3}$ Fatty acids C12:0, C14:1 n-5, C15:0, C16:2 n-4, C17:0, C16:3 n-3, C16:4 n-1, C18:2 n-4, C18:3 n-6, C20:0, C20:1 n-7, C20:2 n-6, C20:3 n-3, C20:3 n-6, C20:4 n-6, C22:1 n-9, C21:5 n-3, C22:4 n-6, $\mathrm{C} 22: 5 \mathrm{n}-6$, in percentage less than $1 \%$, were considered in the composite fractions but not reported in the table for brevity. 
Table 7. Free amino acid content $(\mathrm{mg} / \mathrm{kg})$ in muscle of sea bream fed diets based on fish meal (FM) or on a mixture of plant protein sources (PP) at death and after 11 days of refrigerated storage ${ }^{1}$.

\begin{tabular}{|c|c|c|c|c|c|c|}
\hline & $\mathrm{FM}(\mathrm{n}=3)$ & $\mathrm{PP}(\mathrm{n}=3)$ & rsd & $\mathrm{FM}(\mathrm{n}=3)$ & $P P(n=3)$ & rsd \\
\hline FAA $(\mathrm{mg} / 100 \mathrm{~g})$ & \multicolumn{2}{|c|}{ death } & \multicolumn{4}{|c|}{11 days } \\
\hline O-Phosphoethanolamine ${ }^{2}$ & n.d. & - & - & 109.32 & 245.90 & 147.54 \\
\hline Taurine & 337.61 & 194.29 & 83.172 & 292.05 & 192.86 & 57.22 \\
\hline Threonine & $8.40^{\mathrm{B}}$ & $17.05^{\mathrm{A}}$ & 1.923 & 11.98 & 18.50 & 3.226 \\
\hline Serine & 1.90 & 4.01 & 1.094 & 4.24 & 5.62 & 1.102 \\
\hline Asparagine & 23.92 & 29.68 & 6.998 & $32.89^{\mathrm{b}}$ & $46.74^{\mathrm{a}}$ & 5.924 \\
\hline Glutamic acid & $8.83^{\mathrm{b}}$ & $15.45^{\mathrm{a}}$ & 2.860 & $9.88^{\mathrm{b}}$ & $15.22^{\mathrm{a}}$ & 1.647 \\
\hline Proline & n.d. & 1.80 & - & 1.16 & 4.40 & 1.036 \\
\hline Glycine & 31.22 & 71.59 & 19.038 & $29.78^{\mathrm{B}}$ & $71.59^{\mathrm{A}}$ & 6.574 \\
\hline Alanine & $3.78^{\mathrm{b}}$ & $5.26^{\mathrm{a}}$ & 0.607 & $7.55^{\mathrm{b}}$ & $10.74^{\mathrm{a}}$ & 0.993 \\
\hline Valine & 2.37 & n.d. & - & 4.83 & n.d. & - \\
\hline Cysteine & n.d. & n.d. & - & n.d. & n.d. & - \\
\hline Methionine & n.d. & n.d. & - & n.d. & n.d. & - \\
\hline Leucine & $1.72^{\mathrm{B}}$ & $3.24^{\mathrm{A}}$ & 0.363 & 6.09 & 5.82 & 1.666 \\
\hline Isoleucine & n.d. & 0.77 & - & n.d. & 2.73 & - \\
\hline Phenylalanine & n.d. & n.d. & - & 4.91 & 4.89 & 1.526 \\
\hline Tyrosine & n.d. & n.d. & - & 2.86 & 3.96 & 1.662 \\
\hline Ornithine & $74.11^{\mathrm{a}}$ & $56.88^{\mathrm{b}}$ & 6.209 & $69.14^{\mathrm{a}}$ & $60.59^{\mathrm{b}}$ & 3.342 \\
\hline Lysine & $59.37^{\mathrm{b}}$ & $124.62^{\mathrm{a}}$ & 23.362 & $71.19^{\mathrm{B}}$ & $133.16^{\mathrm{A}}$ & 12.249 \\
\hline Histidine & 32.38 & 57.14 & 11.105 & 42.23 & 60.82 & 8.941 \\
\hline 3-Metilhistidine & 3.73 & 6.70 & 0.490 & 4.59 & 7.57 & 2.480 \\
\hline Arginine & 20.07 & 9.41 & 5.884 & 16.25 & 18.75 & 12.433 \\
\hline$\Sigma \mathrm{AAE}$ & 122.728 & 214.52 & 17.797 & 154.811 & 245.303 & 17.989 \\
\hline$\Sigma \mathrm{AA}$ & 609.23 & 621.36 & 115.10 & $649.732^{\mathrm{b}}$ & $913.236^{\mathrm{a}}$ & 89.618 \\
\hline
\end{tabular}


Table 8. Parameters of fillet and skin colour in sea bream fed diets based on fish meal (FM) or on a mixture of plant protein sources $(\mathrm{PP})^{1}$.

\begin{tabular}{lccccccccc}
\hline & \multicolumn{2}{c}{ Opercular } & \multicolumn{4}{c}{ Abdominal } & \multicolumn{3}{c}{ Rostral } \\
\hline Skin & FM & PP & rsd & FM & PP & rsd & FM & PP & (n=82) \\
colour & $(\mathrm{n}=82)$ & $(\mathrm{n}=82)$ & rs $=82)$ & rsd \\
\hline $\mathrm{L}^{*}$ & $79.59^{\mathrm{A}}$ & $76.30^{\mathrm{B}}$ & 7.11 & $89.02^{\mathrm{a}}$ & $86.67^{\mathrm{b}}$ & 6.65 & 45.72 & 45.00 & 4.97 \\
$\mathrm{a}^{*}$ & $0.39^{\mathrm{A}}$ & $-0.09^{\mathrm{B}}$ & 0.79 & -1.74 & -1.77 & 0.96 & -1.12 & -1.21 & 1.37 \\
$\mathrm{~b}^{*}$ & 3.30 & 3.27 & 1.83 & $1.33^{\mathrm{b}}$ & $1.81^{\mathrm{a}}$ & 1.55 & $-0.52^{\mathrm{B}}$ & $0.38^{\mathrm{A}}$ & 1.28 \\
\hline
\end{tabular}

\begin{tabular}{lccccccccc}
\hline & \multicolumn{3}{c}{ Cephalic epaxial } & \multicolumn{3}{c}{ Ventral } & \multicolumn{3}{c}{ Caudal } \\
\hline $\begin{array}{l}\text { Fillet } \\
\text { colour }\end{array}$ & $\begin{array}{c}\text { FM } \\
(\mathrm{n}=64)\end{array}$ & $\begin{array}{c}\text { PP } \\
(\mathrm{n}=64)\end{array}$ & rsd & $\begin{array}{c}\text { FM } \\
(\mathrm{n}=64)\end{array}$ & $\begin{array}{c}\text { PP } \\
(\mathrm{n}=64)\end{array}$ & rsd & $\begin{array}{c}\text { FM } \\
(\mathrm{n}=64)\end{array}$ & $\begin{array}{c}\text { PP } \\
(\mathrm{n}=64)\end{array}$ & $\mathrm{rsd}$ \\
\hline $\mathrm{L}^{*}$ & $45.31^{\mathrm{b}}$ & $48.61^{\mathrm{a}}$ & 7.70 & 51.38 & 52.78 & 8.77 & 50.46 & 50.69 & 3.66 \\
$\mathrm{a}^{*}$ & -1.73 & -1.71 & 0.62 & 0.33 & 0.02 & 1.16 & 2.73 & 2.32 & 2.48 \\
$\mathrm{~b}^{*}$ & -3.82 & -3.38 & 1.75 & -0.14 & -0.01 & 1.61 & -1.65 & -1.30 & 1.45 \\
\hline
\end{tabular}

${ }^{1}$ Means are indicated with residual standard deviation (rsd).

Different superscript letters in the same row indicate significant statistical differences $(\mathrm{a}, \mathrm{b}: \mathrm{P}<0.05$;

A, B: $\mathrm{P}<0.01)$. 
Fig. 1. Body weight changes in gilthead sea bream fed FM or PP diet and temperature changes over the full annual cycle.

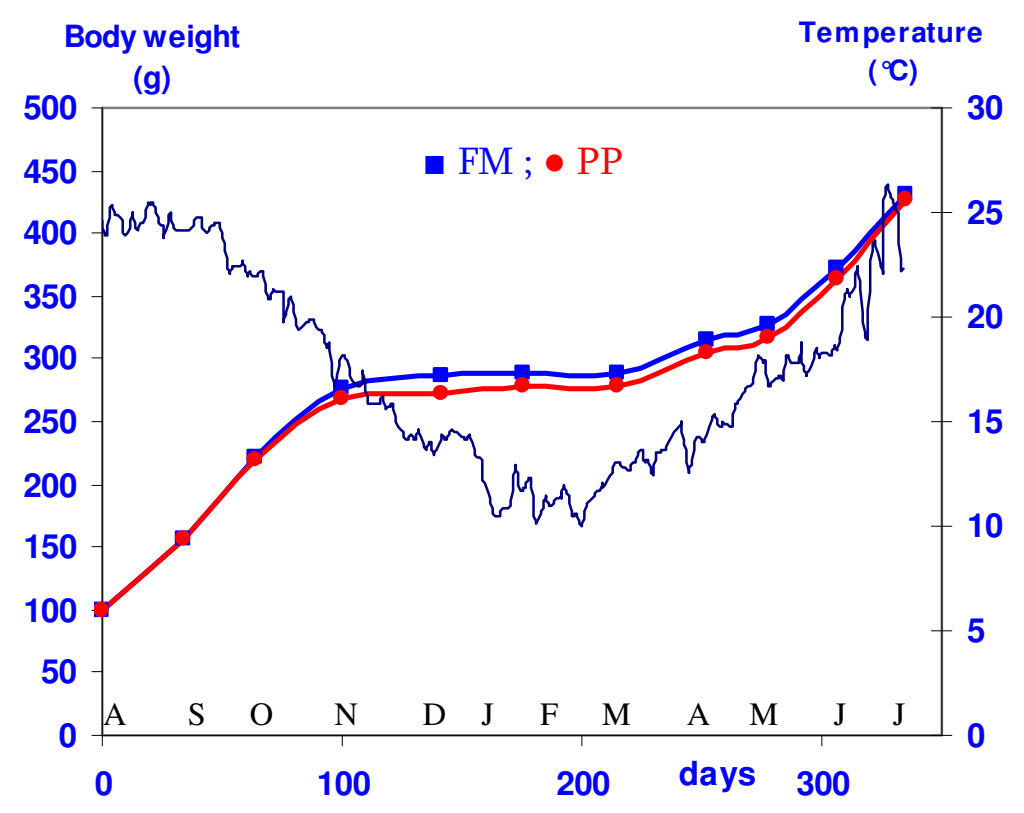

Fig. 2 Linear measurements made by an orthometric meter on whole fish

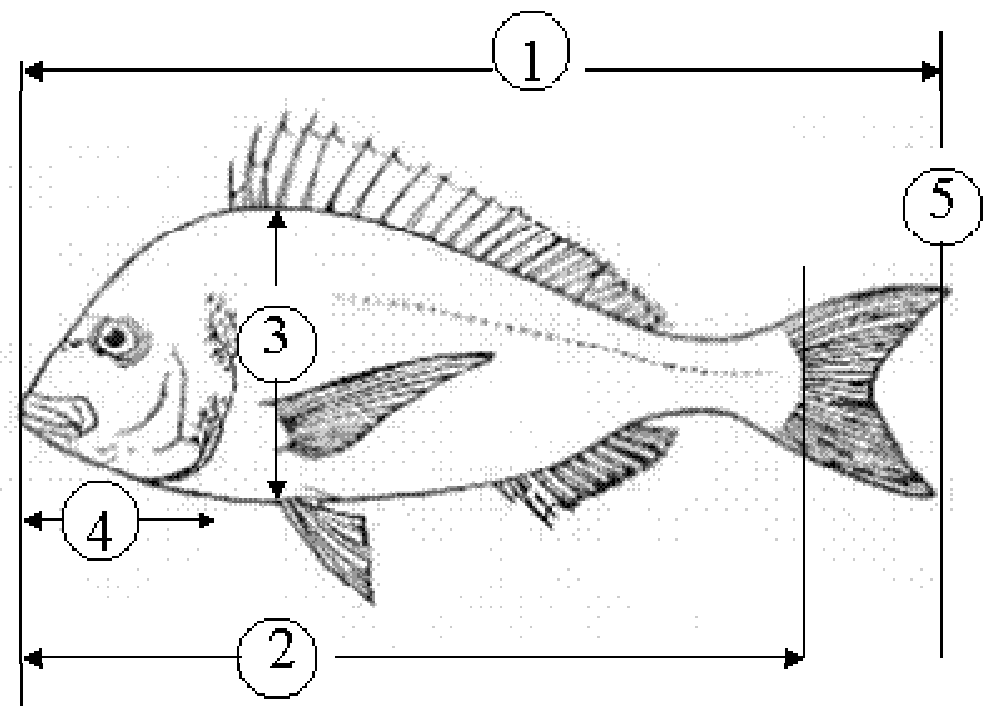

1- Total length

2- Standard length

3- Maximum height

4- Head length

5- Caudal plane 
Scheme 1 - Sampling time table

\begin{tabular}{|c|c|c|c|c|c|c|c|c|c|c|c|}
\hline \multirow[t]{2}{*}{ Parameters } & \multicolumn{11}{|c|}{ Days after death } \\
\hline & 1 & 2 & 3 & 4 & 5 & 6 & 7 & 8 & 9 & 10 & 11 \\
\hline Body measurements & & & & & & & & & & & \\
\hline Free amino acids & & & & & & & & & & & \\
\hline Malonaldehyde & & & & & & & & & & & \\
\hline Skin and fillet colour & & & & & & & & & & & \\
\hline Sensory evaluation & & & & & & & & & & & \\
\hline
\end{tabular}

